\title{
Growth, Diet and Fatty Acid Composition of Gibel Carp Carassius Gibelio in Lake Shira, a Brackish Water Body in Southern Siberia
}

\author{
Denis Yu. Rogozin ${ }^{\mathrm{a}, \mathrm{b} * \text {, }}$ \\ Marina V. Pulyayevskaya ${ }^{b}$, Ivan V. Zuev ${ }^{b}$, \\ Olesya N. Makhutova a and Andrey G. Degermendzhia,b \\ ${ }^{a}$ Institute of Biophysics SB RAS \\ Akademgorodok, Krasnoyarsk, 660036 Russia \\ ${ }^{b}$ Siberian Federal University \\ 79 Svobodny, Krasnoyarsk, 660041 Russia $^{1}$
}

Received 4.03.2011, received in revised form 11.03.2011, accepted 18.03.2011

For the first time the presence of gibel carp Carassius gibelio has been detected in the brackish meromictic Lake Shira (Southern Siberia, Republic of Khakassia). Lake Shira has been continuously studied since the late 19th century, and it has been considered so far that there is no ichthyofauna in the lake. This work investigates the growth and population characteristics, as well as food spectra and fatty acid composition of $C$. gibelio specimen at different ages that were fished out in the summers of 2007 and 2008. The water salinity at the fishing point was $15 \mathrm{gl}^{-1}$. The food spectrum of one- and two-year old C. gibelio was dominated by diatomic, green and blue-green algae, while four- to sixyear old species had an increased share of copepods, beetles and chironomids in their food spectrum, and beginning from the age of six years the amphipods Gammarus lacustris consisted significant part of gibel carp diet. Thus, it was shown that $C$. gibelio is a carnivore with regard to the population of amphipods Gammarus lacustris, which have been regarded so far as the upper link in the trophic cascade of Lake Shira. One of the possible reasons for appearance of fish is the decreased water salinity caused by rising of the lake level. In the recent years, the level of Lake Shira exceeded all the values that had been registered since the late 19th century, and the lake's salinity decreased correspondingly to its smallest value for the whole period of observation.

Keywords: Carassius gibelio, brackish lake, food spectrum, fatty acids.

\section{Introduction}

Fish introductions are amongst the greatest threats to freshwater biodiversity (Gherardi, 2010), and one of the most invasive freshwater fish species is the gibel carp Carassius gibelio Bloch (Szczerbowski, 2002; Luskova et al., 2010) which has been recently found to have established a population in the brackish Lake

\footnotetext{
* Corresponding author E-mail address: rogozin@ibp.ru (C) Siberian Federal University. All rights reserved
} 
Shira previously reported as a fish-less lake (Degermendzhy, Gulati, 2002; Degermendzhy et al., 2010). Gibel carp Carassius gibelio, being a stenohaline species, is rather often observed in brackish water, for example, in the littoral zones of the Black and Baltic seas (Abramenko, 2006; Vetemaa et al., 2005), in the delta of the Ob (Zhadin et al., 1961) etc. Lake Shira has been studied for decades by many researchers (Krivosheyev, Khasanov, 1990; Degermendzhy, Gulati, 2002; and many others), but it has been considered until now that there is no permanent ichtyofauna in the lake (Degermendzhy, Gulati, 2002; Degermendzhy et al., 2010). In summer, the salinity of the epilimnion water was about $15 \mathrm{~g} \mathrm{l}^{-1}$ during last decade (Rogozin et al., 2010), however, lower salinity was observed near estuary of the river Son incoming to the lake. According to the oral evidence of local residents, gibel carp has been regularly observed in the lake lately. However, there have been no reliable facts proving this information so far. In 2007, we made trial sampling that confirmed the presence of gibel carp in the lake. Since the fish population may provide considerable impact on previously fishless ecosystem, it seems to be important to study the main characteristics and ecology of this population. At the first step, we tried to analyze the feeding spectrum, growth characteristics and fatty acids composition of gibel carp in the lake. Fish species, from different ecosystems, are known to differ in their fatty acids composition; therefore, studies of fatty acids contents of diverse fish from various locations are of great importance for revealing their potential value as sources of the essential $\omega 3$ acids for human nutrition (Ahlgren et al., 1994; Gladyshev et al., 2009). Polyunsaturated fatty acids (PUFAs) of the $\omega 3$ family became known as key dietary nutrients for preventing mental, neural and, especially, cardiovascular diseases of human (Arts et al., 2001; Garg et al., 2006). Besides, biochemical analysis of fatty acid composition is widely used to trace trophic interactions between hydrobionts and to reveal food assimilation (Desvilettes et al., 1997; Sushchik et al., 2003). Therefore, the aims of present work were to provide the first evidence of presence of fish in Shira Lake, to analyze the diet of the fish and to give some basic information about growth characteristics and fatty acids composition.

\section{Materials and Methods}

\section{Lake description}

Lake Shira (90.11 E, $54.30 \mathrm{~N}$ ) is located in the northern part of the Republic of Khakassia, South Siberia (Russian Federation). This elliptical $(9.3 \times 5.3 \mathrm{~km})$ lake has an area of $35.9 \mathrm{~km}^{2}$ and maximum depth of $23.8 \mathrm{~m}$ (2007-2010). The main inflow is from the Son River that provides about $42 \%$ of fresh water supply to the lake; other sources of water are precipitation and seepage water (Parnachev et al., 2002). The lake has no outflow. The salinity of lake water during summer stratification is about 14-15 $\mathrm{g} \mathrm{l}^{-1}$ in epilimnion (upper 5-6 m of water column) and 18-19 $\mathrm{g} \mathrm{l}^{-1}$ in deeper waters. The detailed description of the lake is given elsewhere (Degermendzhy et al., 2002; Parnachev et al., 2002; Kalacheva et al., 2002; Rogozin et al., 2010). The surface elevation of Lake Shira has noticeably changed over the whole period of observation. The lake's salinity varied inversely with changes in water volume (Krivosheev, Khasanov, 1990; Rogozin et al., 2010). During the period from 1920 -s to 1930 -s the lake's level decreased by $7 \mathrm{~m}$, which was caused by the decrease in the total amount of precipitation in the region. In this period, salinity reached the maximum of $27 \mathrm{~g} \mathrm{l}^{-1}$ in 1926. By the present moment, the lake level has exceeded all the values registered since the late $19^{\text {th }}$ century, and the salinity has dropped, respectively, to its lowest value for the whole period of observation (Rogozin et al., 2010). 
Sampling and water measurements

Fish sampling was carried out in 2007-2009 in Point A (54.28.767 N, 90.14.818 E), in several points of Area B, and in point C $(54.29 .053 \mathrm{~N}$; 90.16.352 E) (Fig.1). Exact coordinates of Area $B$ point were not defined, and the location of Area B was estimated visually on the basis of landmarks. The dates of fishing are given on Fig.1. Fish were captured with gill nets of various dimensions and mesh sizes, complemented for young specimens by drag-nets, bottle and can traps as well as rod and line angling. In all points the nets were set in the evening, along macrophyte beds, at a depth of approximately $1.5 \mathrm{~m}$ not far from the shore; the nets were checked early in the morning next day.

The temperature and specific conductance of water in points A and C (Fig.1) were measured with YSI 6600 (Yellow Springs, Ohio, USA) submersible profiler. The salinity was calculated as quadratic approximation of the dependence of ash content upon specific conductance measured for the Lake Shira water in laboratory:

$$
\begin{gathered}
S=-0.087 \text { cond }^{2}+4.4403 \text { cond }-37.16, \\
R^{2}=0.95, \mathrm{n}=19,
\end{gathered}
$$

where $S$ is the salinity determined as ash content $\left(\mathrm{g} \mathrm{l}^{-1}\right)$, Cond is specific conductance at $25^{\circ} \mathrm{C}$ of the lake water samples $\left(\mathrm{mS} \mathrm{cm} \mathrm{cm}^{-1}\right)$. Conductivity sensors were calibrated against $3 \mathrm{M} \mathrm{KCl}$ (YSI). Oxygen electrodes were calibrated against Winkler titration of the Lake Shira water with Aquamerck kit (Merck, Germany)

\section{Back-calculated growth, weight-length relationship and Fulton's condition factor}

The growth history was determined for 200 fish collected from the end of July to the beginning of August in Area B (Fig.1). After capture all the fish were individually weighted (wet) to the nearest
$0.01 \mathrm{~g}$ on electronic balances and measured to the nearest millimeter. Scale samples for age and growth analysis were collected from each fish. Scales were taken above the lateral line dorsal to the tip of depressed left pectoral fin. Growth histories of individual fish were determined by aging and back-calculation of total lengths (TL) at previous ages from scales (Pierce et al., 1996). Twelve to fifteen scales per fish were cleaned and mounted between glass slides. All scales on slides were viewed when ages were assigned to fish, and a single reader did all aging. Anterior radii and interannular distances were measured to nearest $0.01 \mathrm{~mm}$ by using dissecting microscope (25× magnification). These radii are hereafter referred to as scale lengths. Replicate measurements were then averaged for each fish, providing the precise estimates of scale lengths for back-calculations. With the data on individual TL and mean scale length, we then back-calculated TL at previous ages using the Fraser-Lee formula (Pierce et al., 1996).

Weight-length relationship and Fulton's condition factor were calculated from the expressions:

(1) $\mathrm{W}=a \mathrm{TL}^{b}$

(2) $\mathrm{K}=100 \mathrm{~W} / \mathrm{SL}^{3}$,

Where $\mathrm{W}$ is the whole body weight in grams, TL the total length, SL is the standard length in centimeters; $a$ and $b$ are the regression constants; the factor 100 is used to bring $\mathrm{K}$ close to unity (Froese, 2006).

\section{Diet analysis}

Diet was assessed on the basis of gut contents determined by dissection of 32 fish collected from the end of July to the beginning of August in Area B (Fig.1). All fish samples were weighted and measured as described above, and their guts were removed immediately, and 
stored in formalin (4\%) until the contents were analysed. The analysis of digestive tracts was performed in accordance with the standard method (Metodicheskoye rukovodstvo, 1974; Hyslop, 1980). Animal food items were identified to the lowest possible taxon. The diet was analyzed for the percentage composition by mass.

\section{Analysis of fatty-acid composition}

Detailed description of the analysis is given elsewhere (Makhutova et al., 2003; Sushchik et al., 2006). Briefly, lipids from samples were extracted with chloroform:methanol $(2: 1, \mathrm{v} / \mathrm{v})$ three times simultaneously with mechanical homogenization of the tissues with glass beads. Before extraction, a fixed volume of an internal standard solution (19:0) was added to the samples. Methyl esters of fatty acids (FAMEs) were prepared in a mixture of methanol: sulphuric acid (50:1, v/v) at $90{ }^{\circ} \mathrm{C}$ for $2 \mathrm{~h}$. FAMEs were then analysed using a $\mathrm{GC}-$ MS (model GCD Plus, Hewlett Packard, USA) equipped with a $30 \mathrm{~m}$ long $\times 0.32 \mathrm{~mm}$ internal diameter capillary column HP-FFAP. FAMEs peaks were identified by their mass spectra, comparing to those in the data base (HewlettPackard, USA) and to those of available authentic standards (Sigma, USA). To determine double bond positions in monoenoic and polyenoic acids, GC-MS of dimethyloxazoline derivatives of FA were used.

\section{Results}

\section{Fishing results}

On July 24 2007, in the Point A (Fig. 1) the water temperature was $24{ }^{\circ} \mathrm{C}$, and salinity was $15.1 \mathrm{~g} \mathrm{l}^{-1}$. The salinity in the central part of the lake at this period was $15 \mathrm{~g} \mathrm{l}^{-1}$, i.e. it was practically the same as in the fishing point. The captured fish included 33 specimens of 2- and 3 -year-old Carassius gibelio, and one 7-year-old specimen of the same species. This was the first ever documented proof of the presence of fish in Lake Shira. The age was determined for six specimens of this capture (Table 1).

On August 9 2008, in Point A the water temperature was $23{ }^{\circ} \mathrm{C}$, and the salinity was $14.7 \mathrm{~g} \mathrm{l}^{-1}$. In this date, 130 two- to four-yearold specimens and 68 five- to eight-year-old specimens were captured using nets with a mesh size of $25 \mathrm{~mm}$ and $40 \mathrm{~mm}$, respectively. The specimens of this capture were analyzed only for fatty-acid composition.

In area B (Fig.1), 200 specimens of Carassius gibelio of different sizes and ages were captured from the end of July to the beginning of August 2008; the water temperature and salinity were not measured. The specimens captured in 2008 in Area B included fish aged from $1+$ to $15+$ years (Fig.2, Table 1), with the predominance of 7-yearold specimens $(26.5 \%)$. Fish aged 5+ and 7+ make up a large part of the captured total -15.5 and $18.0 \%$, respectively, of the total number of captured specimens. There were few specimens older than 8 years in catches. Almost in all age groups the sex ratio was practically 1:1. It was only in the $4+$ and $7+$ age groups that males dominated. The body length of the fish in this sample was from $54 \mathrm{~mm}$ to $460 \mathrm{~mm}$, and the body mass was from 2.47 to $1358 \mathrm{~g}$.

In May 2009, no specimens were caught in points A and C (Fig.1). The water temperature at that time varied within the range of $10.7-13.2{ }^{\circ} \mathrm{C}$, and the salinity was $13.7-14.5 \mathrm{~g} \mathrm{l}^{-1}$.

\section{Weight-length relationship \\ and Fulton's condition factor}

The length-weight relationship calculated for total length data (Table 1), was

$\mathrm{W}=0.012 \mathrm{TL}^{3.134},\left(\mathrm{R}^{2}=0.995, \mathrm{n}=124\right)$ for females,

$\mathrm{W}=0.015 \mathrm{TL}^{3.068},\left(\mathrm{R}^{2}=0.978, \mathrm{n}=76\right)$ for males.

The relationship between TL and SL was

$\mathrm{SL}=0.786 \mathrm{TL}+0.405,\left(\mathrm{R}^{2}=0.998, \mathrm{n}=206\right)$. 


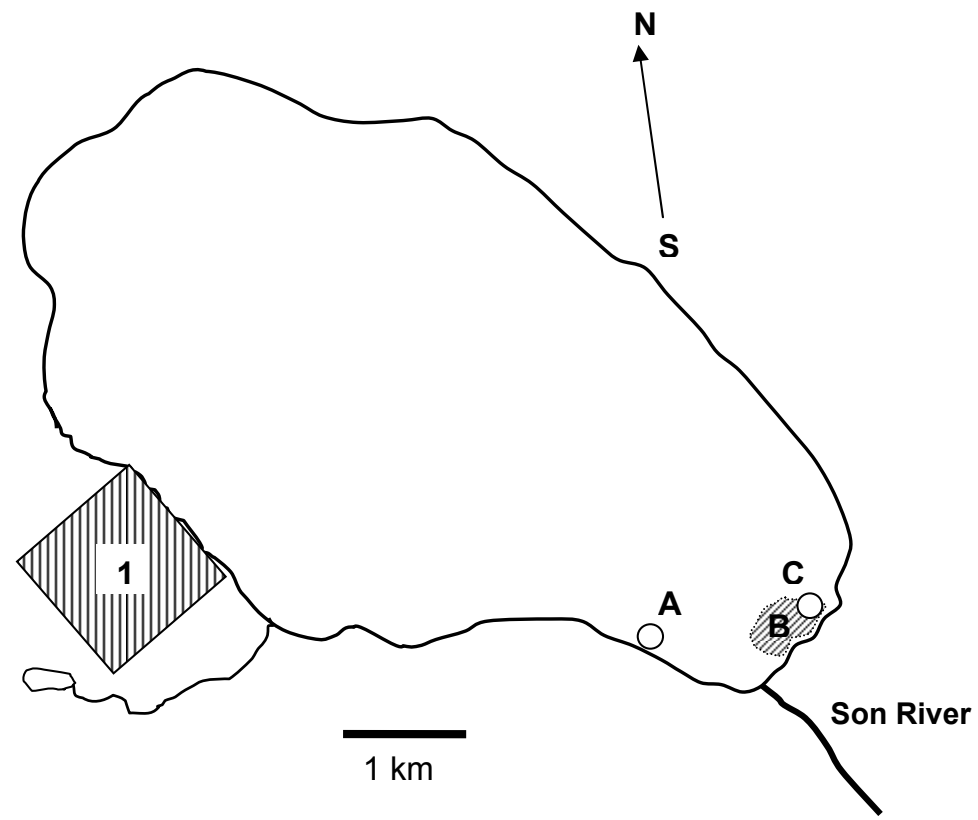

Fig. 1. Fish sampling sites at Shira Lake in 2007-2009: (A) - 24 July 2007, 9 August 2008 and 30 May 2009; Area (B) - 21-30 July and 3-5 August 2008; (C) - 30 May 2009; (1) - Town Zhemchouzhnyi and spa resort "Lake Shira"

Table 1. Length and mass of Carassius gibelio from Lake Shira collected on July, 2007, and July-August, 2008. $\mathrm{M}$ - total mass, $\mathrm{m}$ - mass without entrails

\begin{tabular}{|c|c|c|c|c|c|}
\hline Age & $\mathrm{TL} \pm \mathrm{SE}(\mathrm{cm})$ & $\mathrm{SL} \pm \mathrm{SE}(\mathrm{cm})$ & $\mathrm{M} \pm \mathrm{SE}(\mathrm{g})$ & $\mathrm{m} \pm \mathrm{SE}(\mathrm{g})$ & $\mathrm{n}$ \\
\hline \multicolumn{6}{|c|}{2007} \\
\hline $2+$ & $14.1 \pm 0.3$ & $10.2 \pm 0.5$ & $42.7 \pm 4.6$ & $35.3 \pm 3.5$ & 3 \\
\hline $3+$ & $14.8 \pm 0.6$ & $11.8 \pm 0.3$ & $61.8 \pm 2.1$ & $48.9 \pm 1.6$ & 2 \\
\hline $7+$ & 24.0 & 17.3 & 177 & 133 & 1 \\
\hline \multicolumn{6}{|c|}{2008} \\
\hline $1+$ & $7.3 \pm 1.7$ & $5.5 \pm 1.3$ & $6.4 \pm 0.4$ & $5.1 \pm 0.3$ & 34 \\
\hline $2+$ & - & - & - & - & 0 \\
\hline $3+$ & $14.9 \pm 1.1$ & $12.0 \pm 1.0$ & $54.4 \pm 1.4$ & $47.0 \pm 1.3$ & 21 \\
\hline $4+$ & $16.5 \pm 1.8$ & $13.5 \pm 2.0$ & $83.1 \pm 3.0$ & $68.8 \pm 2.8$ & 10 \\
\hline $5+$ & $18.4 \pm 0.8$ & $14.8 \pm 1.2$ & $114.1 \pm 2.5$ & $92.0 \pm 2.1$ & 31 \\
\hline $6+$ & $19.9 \pm 0.7$ & $16.1 \pm 0.9$ & $149.2 \pm 2.0$ & $122.7 \pm 2.0$ & 54 \\
\hline $7+$ & $21.8 \pm 0.8$ & $17.6 \pm 0.8$ & $182.3 \pm 4.0$ & $147.3 \pm 3.8$ & 36 \\
\hline $8+$ & $23.0 \pm 1.3$ & $18.6 \pm 1.8$ & $210.7 \pm 5.3$ & $170.4 \pm 5.2$ & 10 \\
\hline $9+$ & $25.2 \pm 1.5$ & $20.8 \pm 2.0$ & $308.5 \pm 1.8$ & $265.3 \pm 3.3$ & 2 \\
\hline $10+$ & 26.0 & 21.2 & 301 & 264 & 1 \\
\hline $15+$ & 46.0 & 36.0 & 1358 & 1108 & 1 \\
\hline
\end{tabular}


Table 2. Fulton's condition index $\left(\mathrm{K}_{\mathrm{f}}\right)$ of Carassius gibelio collected from Lake Shira in July and August, 2008

\begin{tabular}{cccccc}
\hline & \multicolumn{2}{c}{ Males } & & \multicolumn{2}{c}{ Females } \\
\hline Age & $\mathrm{K}_{\mathrm{f}}$ & $\mathrm{n}$ & $\mathrm{K}_{\mathrm{f}}$ & $\mathrm{n}$ \\
\hline $1+$ & $3.59 \pm 0.03$ & 30 & $3.79 \pm 0.11$ & 4 \\
$2+$ & - & 0 & - & 0 \\
$3+$ & $3.13 \pm 0.05$ & 13 & $3.22 \pm 0.12$ & 8 \\
$4+$ & - & 0 & $3.41 \pm 0.11$ & 10 \\
$5+$ & $3.33 \pm 0.08$ & 19 & $3.67 \pm 0.08$ & 12 \\
$6+$ & $3.51 \pm 0.04$ & 33 & $3.51 \pm 0.08$ & 21 \\
$7+$ & $3.37 \pm 0.11$ & 18 & $3.29 \pm 0.10$ & 18 \\
$8+$ & $3.15 \pm 0.09$ & 8 & $3.6 \pm 0.01$ & 2 \\
$9+$ & $3.43 \pm 0.08$ & 2 & - & 0 \\
$10+$ & - & 0 & 3.16 & 1 \\
$15+$ & 2.91 & 1 & - & 0 \\
\hline
\end{tabular}

The Fulton's condition index $\left(\mathrm{K}_{\mathrm{f}}\right)$ undergoes minor changes in specimens belonging to different age groups. The $\left(\mathrm{K}_{\mathrm{f}}\right)$ varied from 2.91 to 3.79 (Table 2$)$. The $\left(\mathrm{K}_{\mathrm{f}}\right)$ of males and females was almost equal, except the $5+$ and $8+$ age groups, in which males were noticeably better-fed than females (Table 2).

\section{Growth history}

Generally, the relative length increment estimated from scales decreased with the age (Fig.3, Table 3). The back-calculated patterns of length at the age were similar among six generations, and the year-to-year differences among the fish of equal age-class were not significant, except youngest group of $3+$ (Fig. 3, Table 3). The relative length increment of $3+$ fish in 2005 was significantly higher than for other generations at this age (Fig. 3). However, this may be explained by shortcoming of back-calculation method too (Pierce et al., 1996; Martinson et al., 2000).

\section{Analysis of diet}

The diet of Carassius gibelio in Lake Shira is rather diverse; it includes 4 divisions of algae, 9 groups of water invertebrates, remains of terrestrial insects and higher aquatic vegetation (Table 4, Fig. 4). In addition, the guts of fish in all age groups contained sand which was obviously consumed with food.

The largest number of diatoms was found at the inflow of the River Son. These are diatoms that are preferred by juvenile fish. The algal flora of the lake typically includes algae of Pyrrophyta division, but they were not present in the guts of the caught gibel carps. The cyanobacteria of the genera Spirulina, Oscillatoria, and Anabaena dominating in the littoral zone of the lake were not present in gut contents.

The zooplankton of Lake Shira is characterized by a relatively small diversity of species. The dominating species are Copepoda and Rotatoria (Degermendzhy, Gulati, 2002) which are present in the diet of gibel carp. Several species of Cladocera are found in the south-eastern part of the lake (at the inflow of the River Son). Though their population size and biomass are low, these animals are the most favorite delicacy of gibel carp among all crustaceans. Benthic animals also display little diversity, but they constitute a considerable part of the $C$. gibelio's diet (Table 4, Fig 4). 


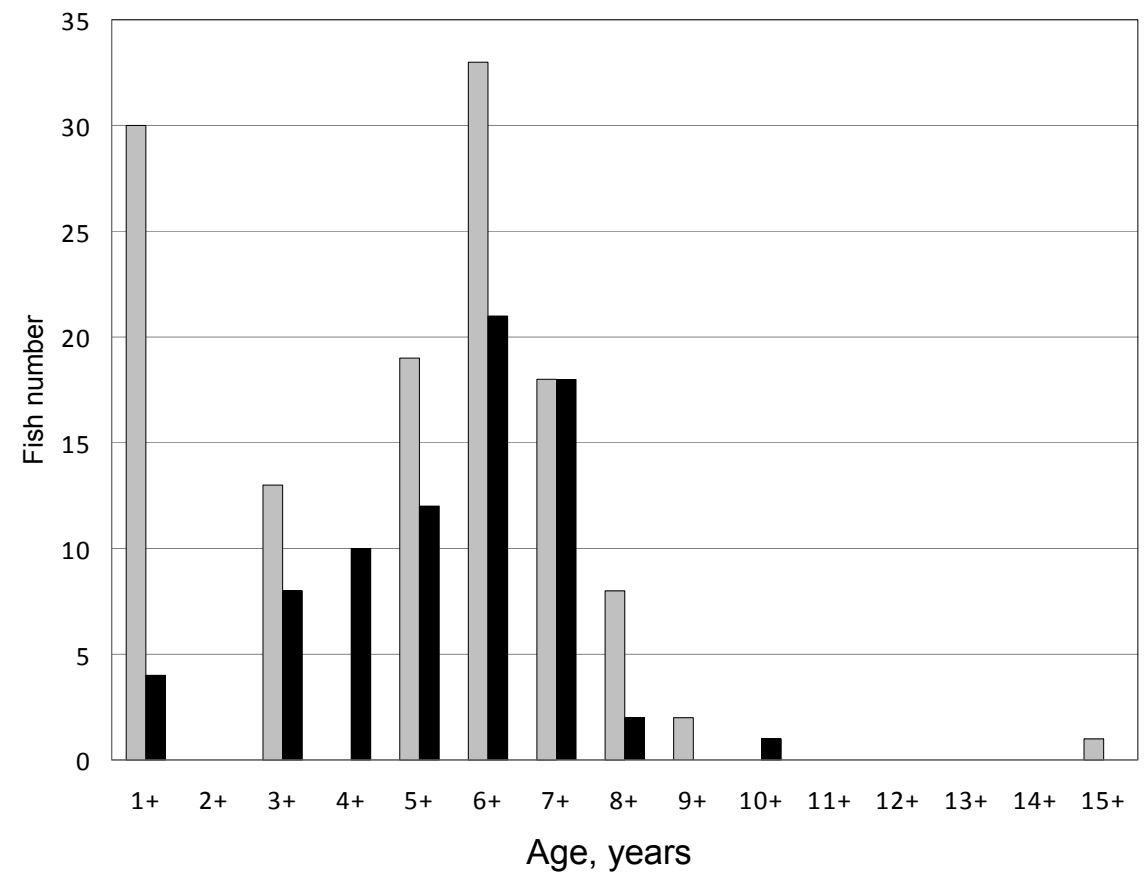

Fig. 2 Age and sex distribution of Carassius gibelio from Shira Lake collected on July-August, 2008. females; males

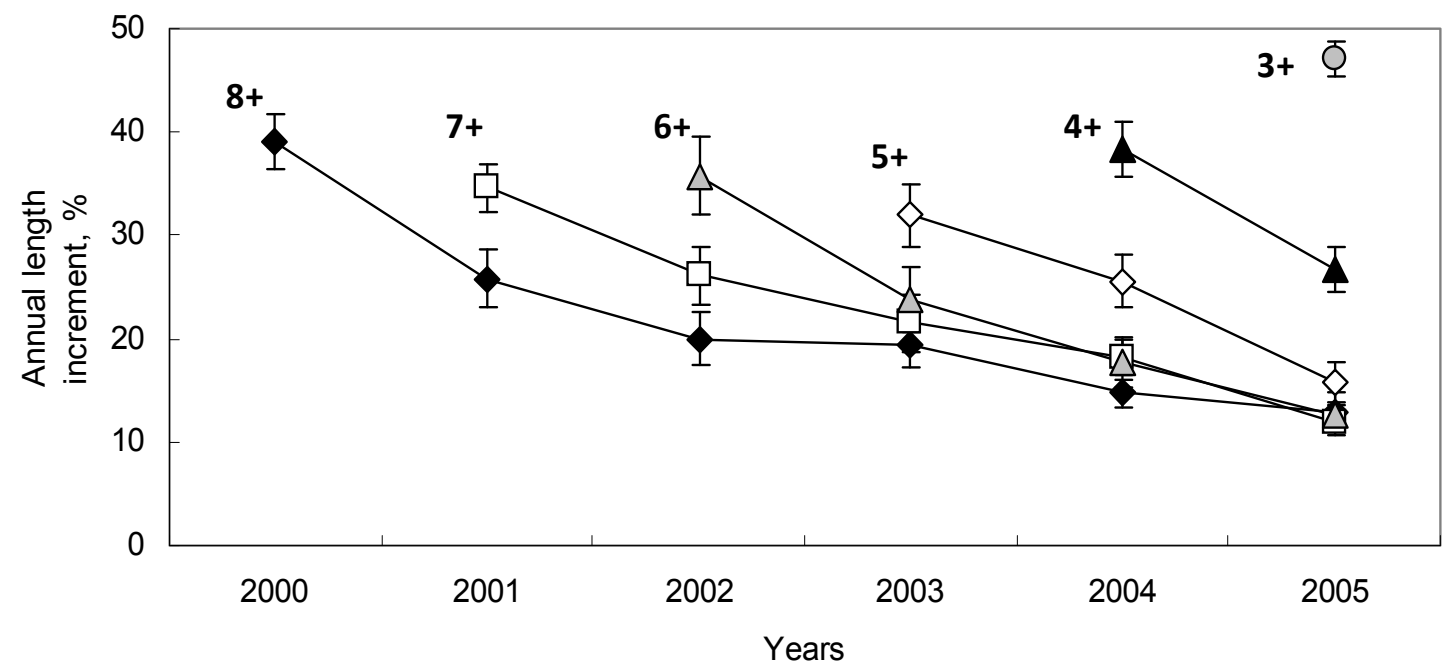

Fig. 3. Back-calculated relative increments of total length of Carassius gibelio from Shira Lake collected on August 2008. Numbers $8+\ldots . .3+$ indicate age at capture 
Table 3. The year of hatching, mean total length at capture, mean back-calculated lengths-at-age, standard errors, and mean annual growth increments of Carassius gibelio from Shira Lake collected in August, 2008. Ten fishes of each age class were analyzed

\begin{tabular}{|c|c|c|c|c|c|c|c|c|c|}
\hline \multicolumn{10}{|c|}{ Back-calculated lengths at age $(\mathrm{mm})$} \\
\hline Year & TL at capture & $1+$ & $2+$ & $3+$ & $4+$ & $5+$ & $6+$ & $7+$ & $8+$ \\
\hline Class & $\frac{\mathrm{TL}}{\mathrm{SE}}$ & $\frac{\mathrm{TL}}{\mathrm{SE}}$ & $\frac{\mathrm{TL}}{\mathrm{SE}}$ & $\frac{\mathrm{TL}}{\mathrm{SE}}$ & $\frac{\mathrm{TL}}{\mathrm{SE}}$ & $\frac{\mathrm{TL}}{\mathrm{SE}}$ & $\frac{\mathrm{TL}}{\mathrm{SE}}$ & $\frac{\mathrm{TL}}{\mathrm{SE}}$ & $\frac{\mathrm{TL}}{\mathrm{SE}}$ \\
\hline 2005 & $\frac{149.0}{1.2}$ & $\frac{57.2}{1.6}$ & $\frac{108.2}{1.9}$ & $\frac{149.0}{1.2}$ & & & & & \\
\hline 2004 & $\frac{165.2}{1.8}$ & $\frac{58.7}{2.1}$ & $\frac{95.2}{2.5}$ & $\frac{129.8}{2.1}$ & $\frac{165.2}{1.8}$ & & & & \\
\hline 2003 & $\frac{183.7}{1.6}$ & $\frac{66.4}{2.2}$ & $\frac{97.6}{2.8}$ & $\frac{131.1}{2.4}$ & $\frac{155.5}{2.3}$ & $\frac{183.7}{1.6}$ & & & \\
\hline 2002 & $\frac{196.6}{1.6}$ & $\frac{61.1}{2.9}$ & $\frac{95.1}{3.1}$ & $\frac{124.8}{3.0}$ & $\frac{151.7}{2.7}$ & $\frac{173.8}{2.4}$ & $\frac{196.6}{1.6}$ & & \\
\hline 2001 & $\frac{218.0}{1.6}$ & $\frac{53.0}{1.5}$ & $\frac{81.1}{2.0}$ & $\frac{109.8}{3.2}$ & $\frac{139.9}{2.8}$ & $\frac{171.0}{0.6}$ & $\frac{194.1}{1.4}$ & $\frac{218.0}{1.6}$ & \\
\hline 2000 & $\frac{230.3}{1.3}$ & $\frac{45.3}{1.5}$ & $\frac{74.3}{2.2}$ & $\frac{100.1}{2.4}$ & $\frac{125.1}{2.8}$ & $\frac{155.0}{1.9}$ & $\frac{181.7}{1.7}$ & $\frac{208.7}{1.5}$ & $\frac{230.3}{1.3}$ \\
\hline Mean T & increment $(\mathrm{mm})$ & 35.0 & 32.2 & 28.4 & 27.9 & 24.2 & 25.4 & 21.6 & \\
\hline
\end{tabular}

Table 4. Food components of Carassius gibelio from Lake Shira collected on July and August, 2008. Numbers indicate weight percentages of a species in a food component

\begin{tabular}{lcccccc}
\hline \multicolumn{1}{c}{ Food component } & \multicolumn{2}{c}{ Fish age } & & & & \\
\multicolumn{1}{c}{1} & $1+$ & $3+$ & $4+$ & $5+$ & $6+$ & $7+$ \\
\hline Bacillariophyta & 2 & 3 & 4 & 5 & 6 & 7 \\
1. Navicula sp. & 39 & - & - & 73 & - & - \\
2. Cymbella sp. & 22 & 70 & 48 & 20 & 80 & 57 \\
3. Sinedra ulna & 8.8 & 20 & 18 & - & - & 20 \\
4. Sinedra acus & 6.9 & - & 14 & 7 & - & 23 \\
5. Melosira sp. & 1.0 & - & - & - & - & - \\
6. Pinnularia sp. & 1.0 & - & 10 & - & - & - \\
7. Gomphonema olivaceum & 0.7 & - & - & - & - & - \\
8. Cocconeis placentula & 2.0 & - & - & - & - & - \\
9. Achnanthes sp. & 0.3 & - & - & - & - & - \\
10. Eunotia sp. & 3.0 & - & - & - & - & - \\
11. Amphora ovalis & 2.0 & - & - & - & - & - \\
12. Rhopalodia gibba & 2.3 & - & 5 & - & - & - \\
13. Cyclotella sp. & 11 & 10 & 5 & - & 20 & - \\
\hline Chlorophyta & 8 & 50 & - & - & - & - \\
14. Staurastrum sp. & 20 & - & - & - & - & - \\
15. Ankistrodesmus sp. & & & & &
\end{tabular}


Table 4. (Continue)

\begin{tabular}{|c|c|c|c|c|c|c|}
\hline 1 & 2 & 3 & 4 & 5 & 6 & 7 \\
\hline 16. Tetraedon minimum & 2 & - & - & - & - & - \\
\hline 17. Scenedesmus quadricauda & 10 & 50 & - & - & 100 & - \\
\hline 18. Scenedesmus acumenatus & 5 & - & 25 & 100 & - & - \\
\hline 19. Pediastrum angulosum & 7 & - & 25 & - & - & - \\
\hline 20. Pediastrum tetras & 10 & - & 25 & - & - & - \\
\hline 21. Cosmarium sp. & 10 & - & 25 & - & - & - \\
\hline 22. Pandorina morum & 10 & - & - & - & - & - \\
\hline 23. Oedogonium sp. & 10 & - & - & - & - & - \\
\hline 24. Dictyosphaerium sp. & 8 & - & - & - & - & - \\
\hline \multicolumn{7}{|l|}{ Cyanophyta } \\
\hline 25. Merismopedia tenuis & 79 & - & - & - & - & - \\
\hline 26. Gomphospheria sp. & 21 & - & - & - & - & - \\
\hline \multicolumn{7}{|l|}{ Euglenophyta } \\
\hline 27. Phacus & 100 & - & - & - & - & - \\
\hline
\end{tabular}

\section{Nemathelmintes}

Rotatoria

Family Asplanchnidae

28. Asplanchna sp.

Family Branchionidae

29. Keratella sp.

90

100

\section{Type Annelida}

Class Oligochaeta

30. Setae of Oligochaeta

Type Mollusca

Sub type Conchifera

31. Class Gastropoda

Type Arthropoda

Class Arachnida

Gen. Acarina

32. Family Hydrocarinae

00

100

100

100

Class Crustacea

Sub class Branchiopoda

Gen. Cladocera

Family Daphniidae

33. Daphnia sp.

Family Bosminidae

34. Bosmina sp.

Family Chydoridae

35. Chydorus sp.

Sub class Copepoda

Gen. Cyclopoida

36. Family Cyclopoidae

37. Gen. Calanoida

10

10

50

75

10

5

10

Class Malacostraca

Gen. Amphipoda

Family Gammaridae

38. Gammarus lacustris
90

78 
Table 4. (Continue)

\begin{tabular}{|c|c|c|c|c|c|c|}
\hline 1 & 2 & 3 & 4 & 5 & 6 & 7 \\
\hline \multicolumn{7}{|l|}{ Class Insecta } \\
\hline \multicolumn{7}{|l|}{$\overline{\text { Gen. Diptera }}$} \\
\hline \multicolumn{7}{|l|}{ Larvae of Chironomidae } \\
\hline 39. Endochironomus sp. & - & 10 & 11 & 20 & 15 & 8 \\
\hline 40. Chironomus sp. & - & 80 & 69 & 70 & 60 & 64 \\
\hline 41. Polypedilum sp. & - & 10 & 10 & - & 15 & 18 \\
\hline 42. Cricotopus sp. & 100 & - & 10 & 10 & 10 & \\
\hline \multicolumn{7}{|l|}{ Gen. Coleoptera } \\
\hline 43. Larvae of beetles & 100 & 100 & - & 100 & 100 & 100 \\
\hline 44. Remains of terrestrial insects & - & - & 100 & 100 & 100 & 100 \\
\hline 45. Remains of macrophytes & - & 100 & 100 & 100 & 100 & 100 \\
\hline 46. Indeterminable substance & 100 & 100 & 100 & 100 & 100 & 100 \\
\hline 47. Sand & 100 & 100 & 100 & 100 & 100 & 100 \\
\hline
\end{tabular}

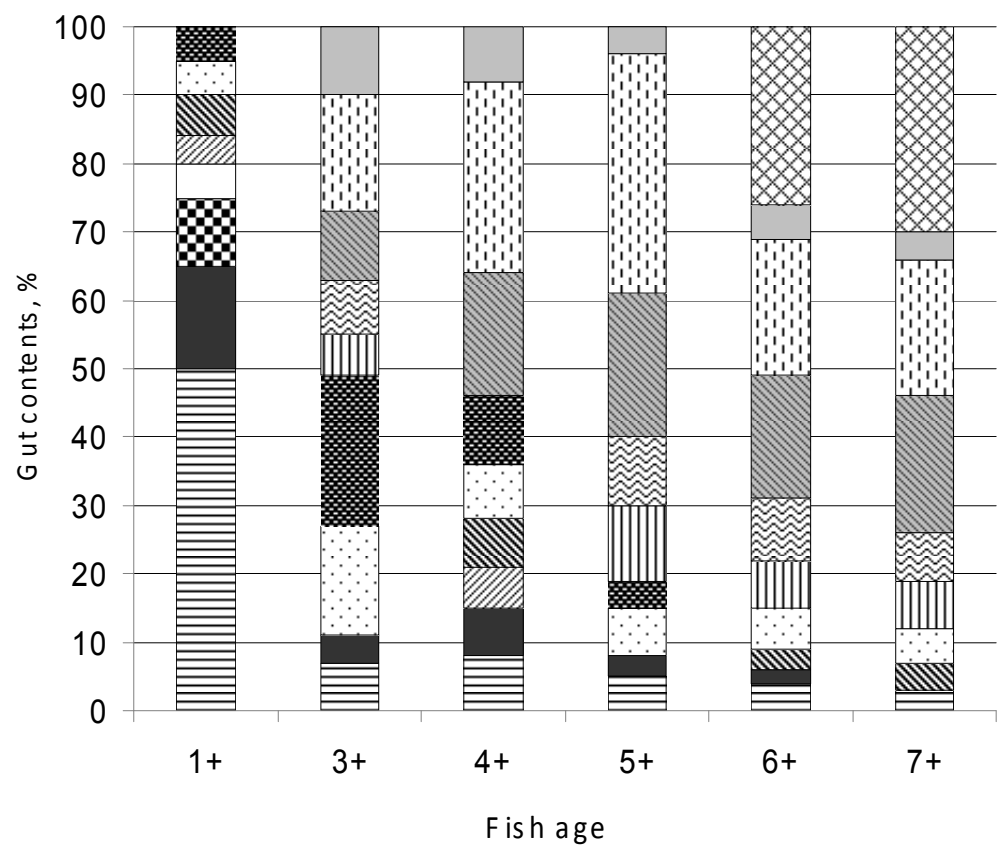

\begin{tabular}{|c|c|c|c|}
\hline$\boxminus$ Bacillariophyta & Chlorophyta & Cyanophyta & $\square$ Euglenophyta \\
\hline Rotatoria & $\mathbb{\mathbb { N } \text { Oligochaeta }}$ & $\square$ Cladocera & Copepoda \\
\hline Ш & $\approx$ Hydrocarinae & $\mathbb{Q}$ Beetles & (1) Chironomidae \\
\hline$\square$ Macrophytes & 凶Gammarus & & \\
\hline
\end{tabular}

Fig. 4 Mass percentage of gut contents components of Carassius gibelio from Lake Shira collected on JulyAugust 2008. Species compositions of components are given in table 4 
The guts collected from Lake Shira were relatively evenly distributed by age groups, which allowed us to reveal differences in the diets of specimens of different ages (Fig. 4). Obviously, the diet is not the same throughout the whole life, the percentage of diet components varies depending on age (Fig. 4). The guts of 2-yearolds contain mostly algae, with the predominance of Bacillariophyta; there are also Rotatoria, Oligochaeta and equal percentage of Cladocera and Copepoda. At an age of $3+$, the percentage of small crustaceans and insects increases, while Gastropoda, Hydrocarina and the remains of higher aquatic vegetation appear in the diet of gibel carp. The percentage of algae is small, while worms are not absent. Chironomidae and Coleoptera are the dominant food category of 5- and 6-year-old specimens. Small crustaceans, gastropods, aquatic mites and worms are also common food for fish of this age group. Older C. gibelio prefer Amphipoda, Chironomida and Coleoptera. The percentage of small crustaceans and worms is insignificant; there are remains of higher aquatic vegetation and sporadic traces of algae (Fig. 4).

\section{Fatty acid composition}

More than sixty fatty acid (FA) species were identified in all muscle samples of $C$. gibelio from the Shira Lake, and percentage of 43 prominent acids are given in Table 5. The average level of saturated fatty acids (SFAs) was $27.8 \%$. Among them 16:0, 18:0 and 14:0 dominated. The percentage of markers of bacterial food, odd and branched acids was 4.7 \%, among them ai17:0 and i17:0 dominated. Monounsaturated fatty acids (MUFAs) were in average $29.8 \%$ (Table 5). Monoenoic acids were primarily represented by $18: 1 \omega 9,16: 1 \omega 7,18: 1 \omega 7$, 20:1 19 . Polyunsaturated fatty acids (PUFAs) were in average $39.9 \%$. Docosahexaenoic acid (DHA, 22:6ஸ3), eicosapentaenoic acid (EPA,

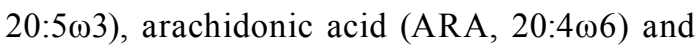

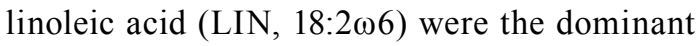
species among PUFAs. The ratio of $\omega 3 / \omega 6$ was 2.8 . It was shown that value of $\omega 3 / \omega 6$ depends on trophic positions of fish e.g., the optimal $\omega 3 / \omega 6$ ratio in the carnivorous-benthivorous freshwater fish is 3.8 , for carnivorouspiscivorous fish the ratio is 2.6, and for herbivorous-omnivorous fish is 2.0 (Ahlgren et al., 2009). Thus, $\omega 3 / \omega 6$ ratio of Carassius gibelio from the Shira Lake corresponds with the ratio for carnivorous-piscivorous fish. The total FA concentration in muscle samples of $C$. gibelio from the Shira Lake was $7.2 \pm 0.7 \mathrm{mg} / \mathrm{g}$ wet weight.

We compared FA content and composition of muscle samples of $C$. gibelio from saline Lake Shira and from the freshwater reservoir Bugach (a small reservoir situated $56^{\circ} 03 \mathrm{~N}$ and $92^{\circ} 43 \mathrm{E}$ in the Bugach river, secondary tributary of the Yenisei river). FA composition of the freshwater and saltwater $C$. gibelio differed significantly (Table 5). C. gibelio from the Shira Lake had higher level of MUFA and BFA, but lower levels of SFA and PUFA in comparison with C. gibelio from Bugach Reservoir (Table 5). Among SFA the levels of dominant FAs, 16:0, 18:0 and 17:0 were significantly higher in freshwater fish. The levels of most fatty acids of MUFA were significantly higher in saltwater population. These differences may be the result of several causes. Firstly, desaturation of 18:0 to $18: 1 \omega 9$ might be more effective in saltwater population. This result is in good agreement with our previous data on freshwater and saltwater populations of Gammarus lacustris (Makhutova et al., 2003). Secondly, differences in nutrition spectrum can take place. The acid 16:1 $\omega 7$ is a marker of diatoms (Claustre et al., 1988/1989; Leveille et al., 1997; Shin et al., 2000). Fatty acids 20:1œ11, $20: 1 \omega 9,20: 1 \omega 7$, as well as $22: 1 \omega 11,22: 1 \omega 9$ and 22:1 107 which obtained in saltwater fish in traces 
Table 5. Average levels (M, \%) of prominent fatty acids in muscles of Carassius gibelio from Shira Lake (n=9) and Bugach Reservoir $(\mathrm{n}=6), \mathrm{t}$ - Student's test, * significant difference. The total, $\mathrm{mg} / \mathrm{g}$ wet weight.

\begin{tabular}{|c|c|c|c|c|c|c|c|}
\hline \multirow{2}{*}{$\begin{array}{c}\text { Fatty acids } \\
1\end{array}$} & \multicolumn{3}{|c|}{$\begin{array}{l}\text { Shira } \\
\mathrm{M} \pm \mathrm{SE}\end{array}$} & \multicolumn{3}{|c|}{$\begin{array}{c}\text { Bugach } \\
\mathrm{M} \pm \mathrm{SE}\end{array}$} & \multirow{2}{*}{$\begin{array}{l}\mathrm{t} \\
4 \\
\end{array}$} \\
\hline & & 2 & & & 3 & & \\
\hline 12:0 & 0.11 & \pm & 0.02 & 0.14 & \pm & 0.02 & 1.06 \\
\hline 14:0 & 1.52 & \pm & 0.19 & 1.19 & \pm & 0.10 & 1.54 \\
\hline 15:0 & 0.82 & \pm & 0.21 & 1.17 & \pm & 0.07 & 1.58 \\
\hline 16:0 & 17.69 & \pm & 0.31 & 22.81 & \pm & 0.79 & $6.03^{*}$ \\
\hline $17: 0$ & 0.74 & \pm & 0.10 & 1.57 & \pm & 0.11 & $5.58^{*}$ \\
\hline 18:0 & 6.50 & \pm & 0.42 & 8.26 & \pm & 0.19 & $3.82 *$ \\
\hline 20:0 & 0.23 & \pm & 0.03 & 0.19 & \pm & 0.01 & 1.26 \\
\hline ai15:0 & 0.22 & \pm & 0.03 & 0.18 & \pm & 0.02 & 1.11 \\
\hline i15:0 & 0.14 & \pm & 0.03 & 0.01 & \pm & 0.003 & $4.31^{*}$ \\
\hline i16:0 & 0.22 & \pm & 0.01 & 0.17 & \pm & 0.01 & $3.54 *$ \\
\hline ai17:0 & 0.79 & \pm & 0.04 & 1.52 & \pm & 0.11 & $6.24 *$ \\
\hline i17:0 & 0.30 & \pm & 0.01 & 0.23 & \pm & 0.01 & $4.95^{*}$ \\
\hline $16: 1 \omega 9$ & 0.18 & \pm & 0.05 & 0.75 & \pm & 0.19 & $2.90^{*}$ \\
\hline $16: 1 \omega 7$ & 6.93 & \pm & 0.71 & 3.24 & \pm & 0.15 & $5.08^{*}$ \\
\hline $16: 1 \omega 5$ & 0.38 & \pm & 0.02 & 0.33 & \pm & 0.03 & 1.39 \\
\hline $17: 1$ & 0.80 & \pm & 0.16 & 0.37 & \pm & 0.04 & $2.61^{*}$ \\
\hline $18: 1 \omega 9$ & 13.09 & \pm & 0.99 & 6.94 & \pm & 1.30 & $3.76^{*}$ \\
\hline $18: 1 \omega 7$ & 5.68 & \pm & 0.17 & 3.73 & \pm & 0.24 & $6.63^{*}$ \\
\hline $18: 1 \omega 5$ & 0.29 & \pm & 0.03 & 0.05 & \pm & 0.01 & $7.59^{*}$ \\
\hline 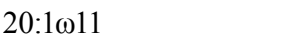 & 0.23 & \pm & 0.04 & 0.09 & \pm & 0.01 & $3.40^{*}$ \\
\hline $20: 1 \omega 9$ & 1.07 & \pm & 0.07 & 0.58 & \pm & 0.03 & $6.43^{*}$ \\
\hline $20: 1 \omega 7$ & 0.44 & \pm & 0.03 & 0.14 & \pm & 0.01 & $9.49 *$ \\
\hline $16: 2 \omega 4$ & 0.43 & \pm & 0.07 & 0.04 & \pm & 0.003 & $5.57^{*}$ \\
\hline $16: 3 \omega 4$ & 0.26 & \pm & 0.05 & tr. & & & \\
\hline $16: 3 \omega 3$ & 0.04 & \pm & 0.01 & 0.01 & \pm & 0.004 & $2.79 *$ \\
\hline $16: 4 \omega 3$ & 0.06 & \pm & 0.01 & 0.03 & \pm & 0.005 & $2.68^{*}$ \\
\hline $16: 4 \omega 1$ & 0.02 & \pm & 0.01 & tr. & & & \\
\hline $18: 2 \omega 6$ & 3.43 & \pm & 0.40 & 3.90 & \pm & 0.86 & 0.50 \\
\hline $18: 2 \omega 4$ & 0.17 & \pm & 0.01 & 0.02 & \pm & 0.01 & $10.61^{*}$ \\
\hline $18: 3 \omega 6$ & 0.26 & \pm & 0.03 & 0.10 & \pm & 0.02 & $4.44^{*}$ \\
\hline $18: 3 \omega 3$ & 1.52 & \pm & 0.14 & 1.58 & \pm & 0.06 & 0.39 \\
\hline $18: 4 \omega 3$ & 0.62 & \pm & 0.10 & 0.27 & \pm & 0.02 & $3.43 *$ \\
\hline $20: 2 \omega 6$ & 0.34 & \pm & 0.03 & 0.41 & \pm & 0.09 & 0.74 \\
\hline $20: 3 \omega 6$ & 0.48 & \pm & 0.03 & 0.39 & \pm & 0.1 & 0.86 \\
\hline $20: 4 \omega 6$ & 4.19 & \pm & 0.27 & 5.46 & \pm & 0.34 & $2.93 *$ \\
\hline $20: 3 \omega 3$ & 0.24 & \pm & 0.02 & 0.37 & \pm & 0.03 & $3.61^{*}$ \\
\hline $20: 4 \omega 3$ & 0.86 & \pm & 0.06 & 0.56 & \pm & 0.02 & $4.74 *$ \\
\hline $20: 5 \omega 3$ & 7.87 & \pm & 0.32 & 6.26 & \pm & 0.49 & $2.75^{*}$ \\
\hline $22: 4 \omega 6$ & 0.29 & \pm & 0.04 & 0.09 & \pm & 0.02 & $4.47^{*}$ \\
\hline
\end{tabular}


Table 5. (Continue)

\begin{tabular}{|c|c|c|c|c|c|c|c|}
\hline 1 & & 2 & & & 3 & & 4 \\
\hline $22: 5 \omega 6$ & 0.98 & \pm & 0.08 & 0.26 & \pm & 0.07 & $6.77 *$ \\
\hline $22: 4 \omega 3$ & 0.02 & \pm & 0.01 & 1.95 & \pm & 0.17 & $-11.33 *$ \\
\hline $22: 5 \omega 3$ & 2.50 & \pm & 0.16 & 2.38 & \pm & 0.33 & 0.33 \\
\hline $22: 6 \omega 3$ & 13.80 & \pm & 1.20 & 21.38 & \pm & 1.66 & $-3.70 *$ \\
\hline SFA & 27.76 & \pm & 0.70 & 35.44 & \pm & 1.13 & $-5.78 *$ \\
\hline BFA & 4.69 & \pm & 0.49 & 2.30 & \pm & 0.1 & $4.78^{*}$ \\
\hline MUFA & 29.75 & \pm & 1.80 & 16.59 & \pm & 1.63 & $5.42 *$ \\
\hline PUFA & 39.91 & \pm & 1.28 & 45.68 & \pm & 1.49 & $-2.94 *$ \\
\hline C18-22 $\omega 3$ PUFA & 27.52 & \pm & 1.27 & 34.76 & \pm & 2.11 & $-2.94 *$ \\
\hline C18-22 $\omega 6$ PUFA & 9.97 & \pm & 0.58 & 10.59 & \pm & 1.03 & -0.52 \\
\hline Total & 7.2 & \pm & 0.72 & 4.54 & \pm & 0.23 & $3.52 *$ \\
\hline
\end{tabular}

are the markers of marine copepods (Mayzaud et al., 1999; Falk-Peterson et al., 2001; Nelson et al., 2001; Scott et al., 2002). Fatty acid 18:107 is considered as marker of bacteria. Thus, perhaps C. gibelio from the Shira Lake fed diatoms and copepods more selectively or in a large quantity. Moreover, the level of PUFA markers of diatoms $(16: 2 \omega 4,16: 3 \omega 4,16: 4 \omega 1$ and 20:5 13$)$ were significantly higher in saltwater population. Among C18-22 PUFA the levels of 18:2 $\omega 4$, $18: 3 \omega 6,18: 4 \omega 3,20: 4 \omega 3,20: 5 \omega 3,22: 4 \omega 6$ and $22: 5 \omega 6$ were significantly higher in saltwater fish. A high level of long-chained fatty acids may be the evidence of prevalence animals in nutrition of $C$. gibelio from the Shira Lake. It should be emphasized that the level of essential, physiologically important acid, 22:6 03 was in two times higher in freshwater population.

The total FA concentration in muscles of C. gibelio from the Shira Lake was in one and a half times higher than in the fish from the Bugach Reservoir. A fattier animal contains a lot of triacylglycerols (TAG), which is characterized by a high level of SFA, though in our case fat less population of $C$. gibelio from the Bugach Reservoir had significantly higher levels of SFA and PUFA (Table 5).

\section{Discussion}

This paper for the first time refers to reliable facts indicating presence of ichthyo-fauna in Shira Lake. Although there is oral evidence that fishermen caught $C$. gibelio at the inflow of the Son River as early as in the 1980 -s, we do not have any evidence referring to an earlier date. Total absence of $C$. gibelio in our catches of May 2009 can be explained by the low water temperature, whereas the salinity at this period had the lowest values as compared to the other dates of sampling.

The length-weight relationship indicates that population of C. gibelio in Shira Lake is relatively well-fed. For example, in femaledominated population of $C$. gibelio from Chimaditis Lake (Greece) the exponent b was 2.81 for TL (Leonardos et al., 2008) (compare to range, 3.13-3.07, in our study). As it was shown by Tsoumani with co-authors (2006), the exponent $b$ may increase with trophic state of the lake. In eutrophic lakes these $b$ values were significantly lower than those in oligotrophic or mesotrophic lakes (Tsoumani et al., 2006). In this respect, the value of $b$ in Shira Lake is close rather to mesotrophic and eutrophic lakes than to oligotrophic ones. According to coefficient $b$ 


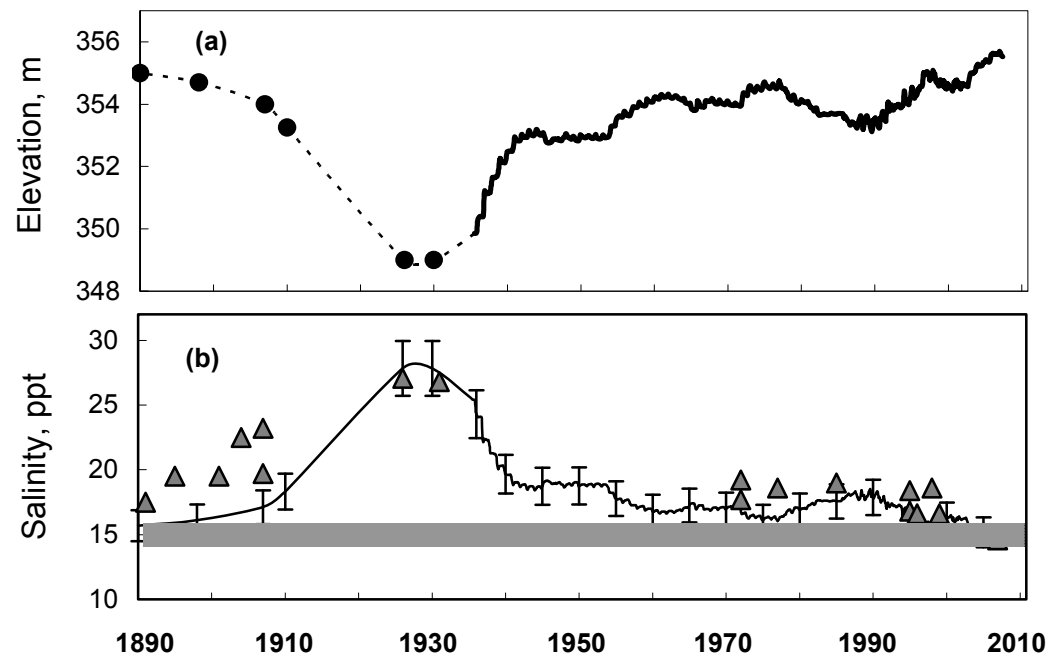

Fig. 5. Surface elevation and salinity of Lake Shira (delivered from Rogozin et al., 2010): (a) surface elevation ASL: ( — ) measured by meteoservice (1936-2007); ( ) -previously reported (Krivosheev, Khasanov, 1990); (b) salinity: ( _ ) average salinity calculated according to estimates of volume change; ( $\triangle$ ) - previously measured and reported (Krivosheev, Khasanov, 1990; Kalacheva et al., 2002; Parnachev et al., 2002; Rogozin et al., 2010); (

values, the females were more "succulent" than males (see Results).

Obviously, absence of other fish species makes gynogenetic reproduction of C.gibelio in Shira Lake impossible. Almost equal sex distribution (Fig. 2) indicates sexual reproduction of C.gibelio in the lake.

We suggest that elevated salinity level has been keeping gibel carp out of the lake. The salt concentration in the lake varied inversely to the lake level (Fig. 5) (Krivosheyev, Khasanov, 1990; Rogozin et al., 2010). In the last two decades the trend has been towards level increase and salinity decrease; in 2007 the historical level maximum occurred, and, therefore, the historical salinity minimum was reached, about 14-15 $\mathrm{g} \mathrm{l}^{-1}$, measured in the epilimnion in summer (Fig. 5).

Therefore, we can assume that the fish range could have expanded throughout the lake in the recent years, and this trend can continue with the lake level increase (and salinity decrease) which might be caused both by increase of climate humidity and inflow of man-made discharge into the lake (Krivosheev, Khasanov, 1990). Apart from the years-long changes, the water salinity in the upper layers of Shira changes during a year with minimum in May and early June (Rogozin et al., 2010). The upper limit of the $C$. gibelio's salinity tolerance is about $15 \mathrm{~g} \mathrm{l}^{-1}$; this species cannot survive for a long time at higher values (Nico, Schofield, 2006). In steppe lakes of Western Siberia the Carassius gibelio is known to withstand the increases of salinity up to 11-14 $\mathrm{g}^{-1}$ (Yadrenkina, Interesova, 2010). However, the salt composition of Shira Lake water is dominated by sulphate-ion (Kalacheva et al., 2002), that makes difficult to compare the salinity tolerance of fish with sea water and other reservoirs where chloride-ion dominates.

Despite many information is available on occurrence of Carassius gibelio and other cyprinids in brackish and mildly saline waters of seas and lakes (Ishitobi et al., 2000; Vetemaa et al., 2005; Abramenko, 2006; Kanaya et al., 2009; Yadrenkina et al., 2010), we could not 
find in literature any study of invasion the fishfree saline lake by fish. Obviously, the invasion of fish-free saline lake is not common event. Therefore, the opportunity to monitor the early point of the invasion stage in a saline lake seems to be very rare. It is not known, however, when exactly the gibel carp appeared in the lake. Apparently, the fish could always be present at the inflow of the river, where the water salinity is minimal.

However, even the minimal salinity values registered by us in the lake are not suitable for normal development of eggs and juveniles of this species (Nico and Schofield, 2006). Thus, the spawning place of the gibel carp living in Lake Shira is not known. Neither is known from what water bodies the gibel carp can enter the Shira Lake, what total biomass this species has in the lake, and what seasonal dynamics this biomass has, and therefore, to what degree C. gibelio influences the biomasses of organisms being its diet components. To answer these questions, further studies are necessary.

\section{Acknowledgements}

We thank Mr. Vladimir Zykov, Mrs. Anastasia Kharuk, Dr. Yury Barkhatov (Institute of Biophysics SD RAS), Mr. Maxim Ousenko and officers of Khakassian National Park for assistance in field work. We are also very grateful to Prof Dr. Anatoly Vyshegorodtsev, Prof. Sergey Chuprov (Siberian Federal University) and two anonymous reviewers for valuable comments and advice on article preparation. This work was partly supported by the Russian Foundation for Basic Research and Krasnoyarsk Regional Science Foundation, Grant No. 09-04-98036, by Siberian Branch of Russian Academy of Sciences, Integrative Project No. 95.

\section{References}

Abramenko M.I. (2000) Carassius auratus gibelio (Bloch) Occur in the Russian Area of the Black Sea. Doklady Biological Sciences (Proceedings of the Russian Academy of Sciences) 374: p.502 (Translated from Doklady Akademii Nauk (2000) 374: 415-418

Ahlgren G., Vrede T., Goedkoop W. (2009) Fatty acid ratios in freshwater fish, zooplankton and zoobenthos - are there specific optima? In: Arts MT Brett MT Kainz MJ (ed) Lipids in aquatic ecosystems, Springer Science+Bisiness Media

Arts M.T., Ackman R.G., Holub B.J. (2001) 'Essential fatty acids' in aquatic ecosystems: A crucial link between diet and human health and evolution. Can J Fish Aquat Sci 58:122-137

Claustre H., Marty J.-C., Cassiani L., Dagaut J. (1988/1989) Fatty acid dynamics in phytoplankton and microzooplankton communities during a spring bloom in the coastal Ligurian Sea: ecological implications. Mar. Micr. Food Webs. 3(2): 51-66

Degermendzhy A.G. and Gulati R.D. (2002) Understanding the mechanisms of blooming of phytoplankton in Lake Shira, a saline lake in Siberia (the Republic of Khakasia). Aquat Ecol 36: 331340

Degermendzhy A.G., Zadereev Y.S., Rogozin D.Y., Prokopkin I.G., Barkhatov Y.V., Tolomeev A.P., Khromechek E.B., Janse J.P., Mooij W.M. and Gulati R.D. (2010) Vertical stratification of physical, chemical and biological components in two saline lakes Shira and Shunet (South Siberia, Russia). Aquatic Ecology 44(3): 619-632. DOI: 10.107/s10452-010-9336-6

Desvilettes C., Bourdier G., Amblard C., Barth B. (1997) Use of fatty acids for the assessment of zooplankton grazing on bacteria, protozoans and microalgae. Freshwater Biol. 38: 629-637 
Falk-Peterson S., Sargent J.R., Kwasniewski S., Gulliksen B., Millar R-M. (2001) Lipids and fatty acids in Clione limacina and Limacina helicina in Svalbard waters and the Arctic Ocean: trophyc implications. Polar. Biol. 24:163-170

Froese R. (2006) Cube law, condition factor and weight-length relationships: history, metaanalysis and recommendations. J. Appl. Ichthyol. 22: 241-253

Garg M.L., Wood L.G., Singh H., Moughan P.J. (2006) Means of delivering recommended levels of long chain n-3 polyunsaturated fatty acids in human diets. J Food Sci 71:66-71

Gladyshev M.I., Sushchik N.N., Makhutova O.N., Kalachova G.S. (2009) Content of essential polyunsaturated fatty acids in three canned fish species. International Journal of Food Sciences and Nutrition 60(3): 224-230

Gherardi F. (2010) Invasive crayfish and freshwater fishes of the world (2010) Revue scientifique et technique-office international des epizooties 29 (2): 241-254

Hyslop E.J. (1980) Stomach contents analysis. A review of methods and their applications. Journal of Fish Biology 17: 411-429

Ishitobi Y., Hiratsuka J., Kuwabara H., Yamamuro M. (2000) Comparison of fish fauna in three areas of adjacent eutrophic estuarine lagoons with different salinities. Journal of Marine Systems 26 (2): 171-181

Kalacheva G.S., Gubanov V.G., Gribovskaya I.V., Gladchenko I.A., Zinenko G.K., Savitsky S.V. (2002) Chemical analysis of Lake Shira water (1997-2000). Aquatic Ecology 36: 123-141

Kanaya G., Yadrenkina E.N., Zuykova E.I., Kikuchi E., Doi H., Shikano S., Mizota C., Yurlova N. (2009) Contribution of organic matter sources to cyprinid fishes in the Chany Lake-Kargat River estuary, western Siberia. Marine and Freshwater Research 60 (6): 510-518

Krivosheev A.S., Khasanov A.P. (1990) Therapeutic lakes of Krasnoyarsk Region. Krasnoyarsk Publishing House, 144 p. (In Russian)

Leonardos I.D., Tsikliras A.C., Eleftheriou V., Cladas Y., Kagalou I., Chortatou R., Papigioti O. (2008) Life history characteristics of an invasive cyprinid fish (Carassius gibelio) in Chimaditis Lake (northern Greece). Journal of Applied Ichthyology 24 (2): 213-217

Leveille J.C., Amblard C., Bourdier G. (1997) Fatty acids as specific algal markers in a natural lacustrian phytoplankton. J. Plankton Res. 19 (4): 469-490

Luskova V., Lusk S., Halacka K., Vetesnik L. (2010) Carassius auratus gibelio - the most successful invasive fish in waters of the Czech Republic. Russian Journal of Biological Invasions 2: 24-28.

Makhutova O.N., Kalachova G.S., Gladyshev M.I. (2003) A comparison of the fatty acid composition of Gammarus lacustris and its food sources from a freshwater reservoir, Bugach, and the saline Lake Shira in Siberia, Russia. Aquatic Ecology 37: 159-167

Martinson E.C., Masuda M.M., Helle J.H. (2000) Back-calculated fish lengths, percentages of scale growth, and scale measurements for two scale measurements methods used in studies of salmon growth. N.Pac. Anadr. Fish Comm. Bull. 2: 331-336

Mayzaud P., Virtue P., Albessard E. (1999) Seasonal variations in the lipid and fatty acid composition of the euphausiid Meganyctiphanes norvegica from the Ligurian Sea. Mar. Ecol. Prog. Ser. 186: 199-210

Metodicheskoye rukovodstvo po izucheniyu pitaniya i pishchevykh otnosheniy ryb v estestvennykh usloviyakh (Textbook on fish diet and trophic relations of fish in natural environments) (1974). Moscow, Nauka, 254 p. (In Russian) 
Nelson M.M., Mooney B.D., Nichols P.D., Phleger C.F. (2001) Lipids of Antarctic Ocean amphipods: food chain interactions and the occurrence of novel biomarkers. Marine Chem. 73: 53-64

Nico L., Schofield P.J. (2006) Carassius auratus. USGS Non-indigenous. Aquatic Species Database, Gainsville, Fl.

Parnachev V.P., Vishnevezky I.I., Makarenko N.A., Petrov A.I., Kopilova J.G., Smetanina O.V., Karnachuk O.V., Turov Y.P., Klopotova N.G., Djabarova N.K., Banks D., Berezovsky A.J. (2002) Natural Waters of Shira District in Khakass Republic/ In: Parnachev V.P.(Ed) Tomsk State University, Tomsk. P.183 (In Russian)

Pierce C.L., Rasmussen J.B., Leggett W.C. (1996) Back-calculation of fish length from scales: empirical comparison of proportional methods. Transactions of the American Fisheries Society 125: 889-898

Pravdin I.F. (1966) Rukovodstvo po izucheniyu ryb (Textbook on fish studies). Moscow, 376 p. (in Russian)

Rogozin D.Y., Zykov V.V., Chernetsky M.Y., Degermendzhy A.G., Gulati R.D. (2009) Effect of winter conditions on distributions of anoxic phototrophic bacteria in two meromictic lakes in Siberia, Russia. Aquatic Ecology 43: 661- 672. DOI: 10.1007/s10452-009-9270-7

Rogozin D.Y., Genova S.V., Gulati R.D., Degermendzhy A.G. (2010) Some generalisations on stratification and vertical mixing in meromictic Lake Shira, Russia, in the period 2002-2009. Aquatic Ecology. DOI: 10.1007/s10452-010-9328-6

Schwartz F.J. (1964) Natural salinity tolerances of some freshwater fishes: Underwater Naturalist 2 (2): $13-15$

Scott C.L., Kwasniewski S., Folk-Petersen S., Sargent J.R. (2002) Species differences, origins and functions of fatty alcohols and fatty acids in the wax esters and phospholipids of Calanus hyperboreus, C. glacialis and C. finmarchicus from Arctic waters. Mar. Ecol. Prog. Ser. 235: 127-134

Shin K.H., Hama T., Yoshie N., Noriki S., Tsunogai S. (2000) Dynamics of fatty acids in newly biosynthesized phytoplankton cells and seston during a spring bloom off the west coast of Hokkaido Island, Japan. Marine Chem.70: 243-256

Sushchik N.N., Gladyshev M.I., Moskvicheva A.V., Makhutova O.N., Kalachova G.S. (2003) Comparison of fatty acid composition in major lipid classes of the dominant benthic invertebrates of the Yenisei river. Compar. Biochem. Physiol., Part B. 134: 111-122

Sushchik N. N., Gladyshev M. I., Kalachova G. S., Makhutova O. N., Ageev A. V. (2006). Comparison of seasonal dynamics of the essential PUFA contents in benthic invertebrates and grayling Thymallus arcticus in the Yenisei River. Comparative Biochemistry and Physiology B, 145: 278-287

Szczerbowski J.A. (2002) Carassius auratus (Linneaus, 1758). In: The freshwater Fishes in Europe. Eds. Banarescu, P.M., Paepke, H.-J. Vol. 5/III. Cyprinidae 2. Wiebelsheim: AULA-Verlag, P. 5-41.

Tsoumani M., Liasko R., Moutsaki P., Kagalou I., Leonardos I. (2006) Length-weight relationships of an invasive cyprinid fish (Carassius gibelio) from 12 Greek lakes in relation to their trophic states. Journal of Applied Ichthiology 22 (4): 281-284

Vetemaa M., Eschbaum R., Albert A., Saat T. (2005) Distribution, sex ratio and growth of Carassius gibelio (Bloch) in coastal and inland waters of Estonia (north-eastern Baltic Sea). Journal of Applied Ichthiology 21(4): 287-291 
Vyshegorodtsev A.A. (2000) Ryby Yeniseya (Fishes of Yenisey River). Novosibirsk: Nauka. (In Russian)

Yadrenkina E.N., Interesova E.A. (2010) Effect of invasive species on fish production of south part of Western Siberia. In: Proceedings of $4^{\text {th }}$ International Conference "Modern problems of Hydroecology", 11-15 October 2010, Sankt-Petersburg, Russia, P. 213

Zhadin V.I., Gerd S.V. (1963) Fauna and flora of the rivers lakes and reservoirs of the U.S.S.R.: Translated from Russian by the Israel Program for Scientific Translations, Jerusalem, 626 p. [Originally published in Moskow, 1961, by Gosudarstvennoe Uchebno-Pedagogicheskoe Izdatelstvo Ministerstva Prosveshcheniya RSFSR.]

\title{
Рост, питание, и жирнокислотный состав серебряного карася Carassius gibelio в солоноватом озере Шира, Южная Сибирь
}

\author{
Д.Ю. Рогозин ${ }^{\mathrm{a}, \tilde{\sigma}}$, М.В. Пуляевская \\ И.В. Зуев ${ }^{\tilde{\sigma}}$, О.Н. Махутова ${ }^{\mathrm{a}}$, А.Г. Дегерменджи ${ }^{\mathrm{a}, \boldsymbol{\sigma}}$ \\ ${ }^{a}$ Институт биофизики СО РАН \\ Россия 660036, Красноярск, Академгородок \\ ${ }^{6}$ Сибирский федеральный университет, \\ Россия 660041, Красноярск, пр. Свободный, 79
}

В солоноватом меромиктическом оз. Шира (Южная Сибирь, Республика Хакасия) зарегистрировано присутствие серебряного карася Carassius gibelio. Озеро Шира непрерывно изучается с кониа ХІХ в., и до сих пор считалось, что ихтиофауна в данном озере отсутствует. В настоящей работе исследуются морфологические характеристики, спектр питания и жирнокислотный состав особей Carassius gibelio различного возраста, выловленных в оз. Шира в летнее время 2007 и 2008 гг. Соленость воды в местах вылова была около 15 г/л. Среди пищевых компонентов особей возраста 1-2 лет преобладали диатомовые, зеленые и сине-зеленые водоросли. У особей от четырех до семи лет в пище увеличивалась доля копепод, жуков и хирономид. Начиная с шестилетнего возраста значительную долю в рационе составляли бокоплавы Gaтmаrus lacustris. Таким образом, серебряный карась может быть хищником по отношению к популящии Gaтmarus lacustris, который до сих пор считался верхним звеном трофического каскада в экосистемы оз. Шира. Одна из возможных причин появления карася в озере - снижение солености, обусловленное повышением уровня озера. $B$ последнее десятилетие уровень оз. Шира превысил все значения, известные для данного озера с кониа ХІХ в. Соответственно, соленость воды в озере снизилась до минимального значения из всех зарегистрированных ранее.

Ключевые слова: серебряный карась, солоноватое озеро, спектр питания, жирные кислоты. 